IHTIYATH Jurnal Manajemen Keuangan Syariah

Vol. 5 No. 1, September 2021

\title{
MANAJEMEN PEMBIAYAAN IJARAH PADA BMT AL FATAYA PAYAKUMBUH
}

\author{
Alges Wahyuni Saputra ${ }^{1}$
}

\begin{abstract}
The background of this research is based on the data, the number of customers of ijarah financing is less than murabahah. two types of financing carried out, the development of financing using murabahah and ijarah contracts is much different because there is no significant increase in customers from year to year. From year to year, the financing offered by BMT Al Fataya should be favored by many customers. The type of research I use is qualitative field research. The results showed that the implementation of the ijarah contract at BMT Al Fataya Payakumbuh, for example for the cost of education, begins with the submission of an application for education financing by the customer to BMT Al Fataya Payakumbuh, if the application for financing is considered complete, the application approved, then BMT Al Fataya made the Al-Ijarah agreement. BMT Al Fataya pays the funds borrowed by the customer to the customer's account at the educational institution where the customer is studying or where his child is studying.
\end{abstract}

Keywords : management, financing, ijarah

\footnotetext{
${ }^{1}$ IAIN Batusangkar, algeswahyunisaputra@gmail.com
} 


\section{PENDAHULUAN}

BMT merupakan bentuk lembaga keuangan dan bisnis yang berupa koperasi atau Lembaga Swadaya Masyarakat (LSM). Segmentasi masyarakat yang biasanya dilayani BMT adalah masyarakat kecil yang kesulitan berhubungan dengan bank. Dalam operasionalnya, BMT ini menitikberatkan pada peningkatan kualitas kehidupan ekonomi sosial masyarakat menengah kebawah. Oleh karena itu, keberadaan BMT diharapkan dapat meningkatkan taraf hidup masyarakat melalui produk yang disediakan, baik hubungannya dengan menabung atau meminjam (Ridwan, 2006: 132).

BMT Al Fataya Payakumbuh merupakan suatu lembaga keuangan mikro syariah berbadan hukum koperasi jasa keuangan syari'ah, dengan akta pendirian No.19 Tgl. 16 Desember 2006, notaris Suhairiadi, SH. Badan hukum No. 18/BH/KUKM-PYK/I/2007, Tgl 04 Januari 2007. Dan telah memiliki aspek legal seperti: SITU/HO, TDP, SIUP, NPWP. BMT Al Fataya manajemen operasionalnya menggunakan pendekatan manajemen koperasi modern sesuai syari'ah sepadan dengan manajemen perbankan syari'ah (Dokumen BMT Al Fataya, 2016).

Salah satu produk yang ditawarkan oleh BMT adalah produk penyaluran dana (financing). Yang bisa disebut dengan produk pembiayaan. Pembiayaan merupakan pendanaan yang diberikan oleh suatu pihak lain untuk mendukung investasi yang telah dilaksanakan, baik yang dilakukan sendiri maupun lembaga. Selain itu, pembiayaan juga merupakan penyelesaian uang atau tagihan yang dipersamakan dengan persetujuan atau kesepakatan antara bank dengan pihak lain, dimana pihak yang dibiayai harus mengembalikan uang atau tagihan tersebut setelah jangka waktu tertentu dengan imbalan atau bagi hasil (Undang-undang RI No. 21 Tahun 2008, 2009: 43).

Terdapat tiga produk pembiayaan (financing) yang telah di laksanakan oleh BMT al-Fataya Payakumbuh, yang bertujuan untuk memberdayakan ekonomi masyarakat. Yang pertama ada produk pembiayaan modal usaha dan modal kerja sesuai syariah, dimana produk ini menggunakan sistem pembiayaan murabahah (sistem jual beli) yang mana pembiayaan dengan prinsip jual beli barang dengan keuntungan/margin yang disepakati, pembayaran dapat diangsur sesuai kesepakatan bersama. Pada produk ini BMT al-Fataya Payakumbuh memberikan dana atau modal pembiayaan kisaran dari Rp 1.000.000 sampai dengan Rp 50.000.000 dan jangka waktu pengembaliannya paling lama dua tahun. Murabahah pada produk ini ada dua kegunaannya yaitu, untuk menambah modal usaha seperti home industry (industri rumah tangga), barang harian dan untuk konsumtif seperti elektronik, perabot dan lain-lain.

Produk pembiayaan yang kedua yaitu produk pembiyaan kebutuhan rumah tangga sesuai syariah. Pada produk ini menggunakan sistem pembiayaan murabahah yang pembayarannya dapat diangsur sesuai kesepakatan bersama dan diperuntukan bagi yang memerlukan asset berupa barang dan tidak ingin melunasinya sekaligus (angsuran). Pada produk ini BMT Al Fataya Payakumbuh juga memberikan dana pembiayaan 
kisaran antara Rp 1.000.000 sampai dengan Rp 50.000.000 dan jangka waktu pengembalian paling lambat dua tahun.

Produk yang terakhir adalah pembiayaan barang jasa (sistem murabahah multijasa), produk ini menggunakan akad ijarah. Pembiayaan atas dasar prinsip jasa, disalurkan untuk berbagai jenis kebutuhan halal seperti: ijaroh multijasa untuk pembayaran biaya pendidikan, pengobatan, sewa tempat dan hiwalah untuk anjak hutang-piutang dan pembiayaan tagihan rekening telepon. Disini BMT Al Fataya Payakumbuh juga memberikan dana pembiayaan kisaran antara Rp 1.000 .000 sampai dengan Rp 50.000.000 dan jangka waktu pengembalian paling lambat dua tahun.

Sampai saat ini, mayoritas produk pembiayaan pada lembaga keuangan syariah masih terfokus pada produk produk murabahah (prinsip jual beli) sama halnya dengan BMT. Pembiayaan murabahah sebenarnya memiliki persamaan dengan pembiayaan ijarah, keduanya termasuk dalam kategori natural certainty contracts dan pada dasarnya adalah kontrak jual beli. Perbedaan keduanya hanyalah objek transaksi yang diperjualbelikan tersebut, dalam pembiayaan murabahah, yang menjadi objek transaksi adalah barang, misalnya rumah, mobil dan sebagainya. Sedangkan dalam pembiayaan ijarah, objek transaksi nya adalah jasa, baik manfaat atas barang maupun manfaat atas tenaga kerja. Jika dengan pembiayaan murabahah, lembaga keuangan syariah hanya dapat melayani kebutuhan nasabah untuk memiliki barang, sedangkan nasabah yang membutuhkan jasa tidak dapat di layani. Dengan skim ijarah, bank syariah dapat melayani nasabah yang hanya membutuhkan jasa (Adiwarman Karim, 2010: 37).

Pembiayaan ijarah sebenarnya dapat dikatakan lebih menarik dibandingkan dengan jenis pembiayaan lainya., karena pembiayaan ijarah mempunyai keistimeaan bahwa untuk memulai sebuah kegiatan usaha, pengusaha tidak perlu memikirkan biaya penyewaan tempat atau toko terlebih dahulu, melainkan dapat melakukan penyewaan kepada BMT. Selain itu nasabah yang membutuhkan biaya pendidikan ataupun biaya pengobatan juga bisa menggunakan akad ijarah yang ditawarkan oleh BMT. Berikut ini perbandingan data jumlan nasabah pembiayaan ijarah dengan pembiayaan lainnya.

Tabel 1.1

Jumlah Nasabah Pembiayaan pada BMT Al Fataya Payakumbuh Tahun 2014-2018

\begin{tabular}{cccccc}
\hline Tahun & Murabahah & Presentase & Ijarah & Presentase & Total Nasabah \\
\hline 2014 & 1.137 & $99 \%$ & 11 & $1 \%$ & 1.148 \\
\hline 2015 & 1.093 & $99 \%$ & 11 & $1 \%$ & 1.104 \\
\hline 2016 & 1.457 & $99 \%$ & 15 & $1 \%$ & 1.472 \\
\hline 2017 & 1.200 & $99 \%$ & 12 & $1 \%$ & 1.212 \\
\hline 2018 & 1.236 & $99 \%$ & 12 & $1 \%$ & 1.248 \\
\hline
\end{tabular}

(Sumber: Documen BMT Alfataya Payakumbuh) 
Berdasarkan tabel 1.1 data jumlah nasabah pembiayaan menggunakan akad ijarah lebih sedikit dari pada murabahah. dari dua jenis pembiayaan yang dilakukan, perkembangan pembiayaan mengguanakan akad murabahah dan ijarah jauh berbeda karena tidak adanya peningkatan nasabah secara signifikan dari tahun ke tahun. Seharusnya dari tahun ke tahun pembiayaan yang ditawarkan oleh BMT Al Fataya banyak digemari oleh nasabah.

Berdasarkan tabel 1.1 dapat dilihat bahwa pembiayaan ijarah merupakan pembiayaan yang jarang dilakukan dengan rata-rata $1 \%$ setiap tahunnya, sedangkan pembiayaan murabahah memiliki rata-rata $99 \%$ pertahunnya. Maka dari itu penulis ingin mengetahui bagaimana persepsi nasabah terhadap produk pembiayaan ijarah pada BMT Al Fataya Payakumbuh.

Dari hal diatas, penulis tertarik untuk melakukan kajian lebih dalam dalam bentuk pene.litian ilmiah dengan judul "MANAJEMEN PEMBIAYAAN IJARAH PADA BMT AL FATAYA PAYAKUMBUH".

Berdasarkan fokus penelitian maka fokus dari penelitian ini adalah:

1. Bagaimana pelaksanaan pembiayaan ijarah pada BMT Al Fataya Payakumbuh?

2. Bagaimana strategi pemasaran pembiayaan ijarah pada BMT Al Fataya Payakumbuh?

\section{Manajemen}

\section{a. Pengertian Manajemen}

Dalam bahasa Arab, manajemen disebut dengan idarah, diambil dari kata adartasy syai' $a$ atau perkataan adartabihi juga berdasarkan pada adarta bihiitulah yang lebih tepat. Dalam Al-Quran hanya ada kata tadbir, merupakan bentuk masdar dari dabara, yudabbiru, tadbiran. Yang berarti penerbitan, pengaturan, pengurusan, perencanaan dan persiapan (Mafruhah, 2007).

Manajemen berasal dari kata to manage yang artinya mengatur, pengaturan dilakukan melalui proses dan diatur berdasarkan urutan dari fungsi-fungsi manajemen itu. Jadi manajemen merupakan suatu proses untuk mewujudkan tujuan yang diinginkan (Muhammad, 2004). Istilah manajemen mengandung tiga pengertian yaitu pertama, manajemen sebagai suatu proses, kedua, manajemen sebagai kolektivitas orang-orang yang melakukan aktifitas manajemen, ketiga, manajemen sebagai suatu seni dan sebagai suatu ilmu. Maka manajemen dapat diberi defenisi sebagai: "seni dan ilmu perencanaan, pengorganisasian, penyusunan, pengarahan, dan pengawasan sumber daya untuk mencapai tujuan yang sudah ditetapkan (Kasmir, 2018).

\section{b. Fungsi-fungsi Manajemen}

Fungsi manajemen adalah serangkaian kegiatan yang dijalankan dalam manajemen berdasarkan fungsinya masing-masing dan mengikuti satu tahapan-tahapan tertentu dalam pelaksanaannya. Fungsi manajemen terdiri dari empat fungsi, yaitu: 
1) Perencanaan atau planing

Perencanaan merupakan suatu proses mengembangkan tujuan-tujuan perusahaan serta memilih serangkain tindakan (strategi) untuk mencapai tujuan tersebut. Fungsi perencanaan akan memerikan arah kepada perusahaan dengan menetapkan terlebih dahulu tujuan yang ingin dicapai. Tanpa adanya tujuan yang jelas yang dirumuskan dalam kegiatan perencanaan, perusahaan tidak akan memiliki hasil akhir yang jelas utuk dicapai selama kurun waktu tertentu. Selain itu ketiadaan tujuan akan menyulitkan perusahaan untuk melakukan proses evaluasi yang merupakan perbandingan antara rencana dengan realisasi pencapaian sesungguhnya. Dalam hal ini berlaku peribahasa "fail to plan is planing to fail" (kegagalan membuat rencana sebuah rencana menuju kegagalan) (Solihin, 2009: 4).

2) Pengorganisasian atau organizing

Pengorganisasian merupakan proses penyusunan orang dan sumber daya fisik untuk melaksanakan rencana dalam mencapai tujuan organisasi. Dan juga merupakan tahapan lanjutan setelah perencanaan dapat berjalan efektif dan efisien. Hasil dari pengorganisasian adalah struktur organisasi formal dimana struktur organisasi formal ini akan menetapkan tanggung jawab masing-masing bagian yang akan terlibat didalam melaksanakan rencana. Dengan adanya struktur organisasi formal maka akan terbentuk garis komunikasi yang jelas yang terkait dengan otoritas posisi seseorang di dalam organisasi (Sulhan \& Siswanto, 2008).

3) Pelaksanaan atau actuating

Pelaksanaan adalah perwujudan dalam tindakan dari rencana yang telah digariskan guna mencapai tujuan atau target organisasi yang telah digariskan. Di dalam melaksanakan suatu rencana manajer harus membuat penjadwalan aktivitas. Penjadwalan aktifitas tersebut terdiri dari dua kategori, yang pertama adalah loading yang kedua adalah dispatching. loading mengacu kepada penugasan kerja kepada beberapa fungsi atau departemen sedangkan dispatching mengacu kepada penjadwalan aktual terhadap aktivitas spesifik fungsi atau departemen. Dari loading dan dispatcing akan diketahui standar waktu yang disediakan oleh organisasi dan waktu yang diserap untuk melakukan suatu pekerjaan. Dari sini dapat dianalisis apakah waktu yang disediakan atau ditetapkan tersebut sesuai dengan kenyataan atau tidak. Jika standar waktu yang digariskan melalui metode ilmiah serta diukur dengan metode studi gerak waktu itu sudah benar maka setiap perbedaan negatif dianggap penyimpangan dan harus diketahui sebabnya (Sulhan \& Siswanto, 2008).

4) Pengawasan atau controling

Pengawasan merupakan proses yang dilakukan untuk memastikan seluruh rangkaian kegiatan yang telah direncanakan, di organisasikan, dan diimplementasikan bisa berjalan sesuai dengan target yang diharapkan sekalipun berbagai perubahan terjadi dalam lingkungan dunia bisnis yang dihadapi (Tisnawati, 2006:8). 


\section{c. Pentingnya Manajemen}

Di zaman sekarang ini, hampir tidak mungkin kebutuhan hidup manusia dapat diperoleh sendiri tanpa bantuan manusia lain dan saran pendukung (alat-alat). Dalam mencapai tujuan, penting manusia senantiasa memperhatikan kerja sama dengan manusia lain dan saran pendukungnya. Dengan mengerti manjemen, manusia secara rasional akan bertindak secara efektif dan efisien. Menghindari dari proses manajemen berarti rela tidak memperoleh tujuan organisasi secara optimal, efektif, dan efisien. Melalui manajemen manusia akan saling mengerti dan memahami kekurangan dan kelebihan masing-masing (Sulhan \& Siswanto, 2008).

\section{Pembiayaan}

\section{a. Pengertian Pembiayaan}

Pembiayaan atau financing adalah pendanaan yang diberikan oleh suatu pihak kepada pihak lain untuk mendukung investasi yang telah direncanakan, baik yang dilakukan sendiri maupun lembaga. Dengan kata lain, pembiayaan adalah pendanaan yang dikeluarkan untuk mendukung investasi yang telah direncanakan. Dalam kaitannya dengan pembiayaan pada perbankan islam atau istilah teknisnya sebagai aktiva produktif. Aktiva produktif adalah penanaman dana bank Islam, baik dalam rupiah maupun valuta asing (Rivai \& Veithzal, 2008).

\section{b. Tujuan Pembiayaan}

Tujuan pembiayaan dibedakan menjadi dua kelompok, yaitu: tujuan pembiayaan untuk tingkat makro, dan tujuan pembiayaan untuk tingkat mikro. Secara makro, pembiayaan bertujuan untuk:

1) Peningkatan ekonomi umat. Masyarakat yang tidak dapat akses secara ekonomi,dengan adanya pembiayaan mereka dapat melakukan akses ekonomi. Dengan demikian dapat meningkatkan taraf ekonominya;

2) Tersedianya dana bagi peningkatan usaha. Untuk pengembangan usaha membutuhkan dana. Dana tambahan ini dapat diperoleh dengan melakukanaktivitas pembiayaan. Pihak yang surplus dana menyalurkan kepada pihak minus dana, sehingga dapat tergulirkan;

3) Meningkatkan produktivitas. Pembiayaan memberikan peluang usaha bagi masyarakat agar mampu meningkatkan daya produksinya. Sebab upaya produksi tidak akan dapat jalan tanpa adanya dana;

4) Membuka lapangan kerja baru. Dengan dibukanya sektor-sektor usahamelalui penambahan dana pembiayaan, maka sektor usaha tersebut akan menyerap tenaga kerja. Hal ini berarti menambah atau membuka lapangan kerja baru;

5) Terjadi distribusi pendapatan. Masyarakat usaha produktif mampu melakukan aktivitas kerja, berarti mereka akan memperoleh pendapatan dari hasil usahanya. Penghasilan merupakan bagian dari pendapatan masyarakat (Muhammad, 2004). 


\section{c. Fungsi Pembiayaan}

Pembiayaan yang dilaksanakan bank syariah secara umum berfungsi untuk:

1) Meningkatkan Daya Guna

Para penabung menyimpan uangnya di bank dalam bentuk giro, tabungan atau deposito. Uang tersebut dalam presentase tertentu ditingkatkan kegunaannya oleh suatu bank guna suatu usaha peningkatan produktivitasnya. Dengan demikian dana yang mengendap di bank (yang diperoleh dari para penyimpan uang) tidak idle (diam) dan disalurkan untuk usaha-usaha yang bermanfaat bagi pengusaha maupun masyarakat.

2) Meningkatkan daya guna barang

Produsen dengan bantuan pembiayaan bank dapat mengubah bahan mentah menjadi bahan jadi sehingga utility bahan tersebut meningkat. Contoh peningkatan utility kelapa menjadi kopra dan selanjutnya menjadi minyak kelapa. Produsen dengan bantuan pembiayaan dapat memindahkan barang dari suatu tempat yang kegunaannya kurang ke tempat yang lebih bermanfaat.

3) Meningkatkan Peredaran Uang

Pembiayaan yang disalurkan melalui rekening-rekening Koran pengusaha menciptakan pertambahan peredaran uang giral dan sejenisnya seperti cek, bilyet, giro, wesel, promes, dan sebagainya. Melalui pembiayaan, peredaran uang kartal maupun giral akan lebih berkembang karena pembiayaan menciptakan suatu kegairahan berusaha sehingga penggunaan uang akan bertambah, baik secara kualitatif maupun kuantitatif.

4) Menimbulkan Kegairahan Berusaha

Pembiayaan yang diterima pengusaha dari bank kemudian digunakan memperbesar volume usaha dan produktifitasnya.

5) Stabilitas Ekonomi

Dalam ekonomi yang kurang sehat, langkah-langkah stabilitas diarahkan pada usaha-usaha:

a) Pengendalian inflasi

b) Peningkatan ekspor

c) Pehabilitasi prasarana

d) Pemenuhan kebutuhan pokok rakyat untuk menekan arus inflasi dan untuk usaha pembangunan ekonomi maka pembiayaan memegang peran penting.

6) Jembatan untuk meningkatkan pendapatan nasional

Para usahawan memperoleh pembiayaan untuk meningkatkan usahanya. Peningkatan usaha berarti peningkatan profit. Bila keuntungan ini secara kumulatif 
dikembangkan lagi kedalam struktur permodalan, maka peningkatan akan berlangsung terus-menerus (Yudiana, 2014).

\section{Pembiayaan Ijarah}

\section{a. Pengertian Ijarah}

Transaksi non bagi hasil selain yang berpola jual beli adalah transaksi berpola sewa atau ijarah. Ijarah, biasa juga disebut sewa, jasa, atau imbalan adalah akad yang dilakukan atas dasar suatu manfaat dengan imbalan jasa. Ijarah adalah istilah dalam Fikih Islam dan berarti memberikan sesuatu untuk disewakan. Menurut Sayyid Sabiq, ijarah adalah suatu jenis akad untuk mengambil manfaat jalan penggantian. Jadi hakikatnya ijarah adalah penjualan manfaat (Ascarya, 2008: 99).

Lafal al-ijarah dalam bahasa Arab berarti upah, sewa, jasa, atau imbalan. Al-ijarah merupakan salah satu bentuk kegiatan muamalah dalam memenuhi keperluan hidup manusia, seperti sewa-menyewa, kontrak, menjual jasa perhotelan, dan lain-lain (Santoso \& Anik, 2015). Al- ijarah adalah akad pemindahan atas barang atau jasa, melalui pembayaran upah sewa, tanpa diikuti dengan pemindahan kepemilikan (ownership/milkiyyah) atas barang itu sendiri. (Antonio, 2001).

\section{b. Prinsip Ijarah}

Transaksi ijarah dilandasi adanya perpindahan manfaat (hak guna), bukan pemindahan kepemilikan (hak milik). Jadi pada dasarnya prinsip ijarah sama saja dengan prinsip jual beli, tetapi perbedaannya terletak pada objek teransaksinya. Bila pada jual beli objek transaksinya adalah barang maupun jasa.

Pada dasarnya, ijarah didefenisikan sebagai hak untuk memanfaatkan barang atau jasa dengan membayar imbalan tertentu. Menurut Fatwa Dewan Syariah Nasional, ijarah adalah akad pemindahan hak guna (manfaat) atas suatu barang atau jasa dalam waktu tertentu melalui pembayaran sewa/upah, tanpa diikuti dengan pemindahan kepemilikan barang itu sendiri. Dengan demikian, dalam akad ijarah tidak ada perubahan kepemilikan, tetapi hanya pemindahan hak guna saja dari yang menyewakan kepada penyewa (Karim, 2010).

Berakhirnya Akad Ijarah Para ulama menyatakan bahwa akad ijarah akan berakhir apabila:

1) Obyek hilang atau musnah, seperti rumah sewaan terbakar dan lain sebagainya.

2) Waktu perjanjian berakhir. Apabila yang disewakan itu rumah, maka rumah itu dikembalikan ke pemiliknya. Apabila yang disewa itu adalah jasa seseorang, maka ia berhak menerima upahnya.

3) Karena pembatalan oleh kedua pihak yang berakad, sebagaimana pembatalan dalam akad jual beli.

4) Menurut ulama Hanâfiyah berakhirnya akad ijarah karena salah satu pihak yang berakad meninggal sebab akad ijârah tidak dapat diwariskan. Sedangkan menurut 
jumhur ulama, akad ijârah tidak batal/berakhir dengan wafatnya salah seorang berakad, karena manfaat boleh diwariskan dan ijârah sama dengan jual-beli, yaitu mengikat kedua belah pihak yang berakad.

5) Merujuk pada Buku 2 Kompilasi Hukum Ekonomi Syariah Bab X tentang Ijarah pasal 253 dinyatakan bahwa: "Akad ijarah dapat diubah, diperpanjang, dan atau dibatalkan berdasarkan kesepakatan” (Santoso \& Anik, 2015).

\section{Baitul Mall wa Tamwil (BMT)}

\section{a. Pengertian Baitul Mall wa Tamwil (BMT)}

BMT merupakan singkatan dari Baitul Maal wa Tamwil atau dapat juga ditulis dengan baitul maal wa baitul tamwil. Secara harfiah lughowi, baitul maal berarti rumah dana dan baitul tamwil berarti rumah usaha. Baitul Maal dikembangkan berdasarkan sejarah perkembangannya, yakni mulai dari masa nabi sampai abad pertengahan perkembangan islam, dimana baitul maal berfungsi untuk mengumpulkan serta mentasyarufkan dana sosial. Sedangkan baitul tamwil merupakan lembaga bisnis yang bemotif laba (Muhammad, 2004).

Baitul Maal wa Tamwil (BMT) atau Balai Usaha Mandiri Terpadu adalah lembaga keuangan mikro yang dioperasikan dengan prinsip bagi hasil, menumbuhkembangkan usaha mikro dalam rangka mengangkat derajat dan martabat serta membela kepentingan kaum fakir miskin, ditumbuhkan atas prakarsa dan modal awal dari para tokoh masyarakat setempat dengan berlandaskan pada system ekonomi yang salam: keselamatan (berintikan keadilan), kedamaian dan kesejahteraan. BMT merupakan badan atau lembaga yang dapat meningkan kinerja perekonomian dan sekaligus mengentaskan kemiskinan, sehingga tercapai kesejahteraan umat (Saputra, 2016: 123).

Dari pengertian tersebut dapatlah kesimpulan bahwa BMT merupakan organisasi bisnis yang juga berperan sosial. Peran sosial BMT akan terlihat pada defenisi baitul maal sedangkan peran bisnis BMT akan terlihat pada defenisi baitul tamwil. Sebagai lembaga sosial baitul maal memiliki kesamaan fungsi dan peranan dengan Lembaga Amil Zakat (LAZ), oleh karenanya baitul maal ini harus didorong agar mampu berperan secara professional menjadi LAZ yang mapan. Fungsi tersebut paling tidak meliputi upaya pengumpulan zakat, infaq, sedekah, dan sumber dana sosial lainnya dan upaya pensyarufan zakat kepada golongan yang paling berhak sesuai dengan ketentuan asnobiah(UU Nomor 38 tahun 1999).

\section{b. Produk pembiayaan BMT}

Pembiayaan yang diberikan oleh BMT diantaranya:

1) Pembiayaan Ba'i Bithman Ajil (BBA), adalah suatu perjanjian pembiayaan yang disepakati antar BMT dengan anggotanya. Dimana BMT menyediakan dananya untuk sebuah investasi atau pembelian barang modal dan usaha anggotanya yang 
kemudian proses pembayarannya dilakuakan secara mencicil atau angsuran. Disini BMT menggunakan akad jual beli.

2) Pembiayaan murabahah (MBA), pembiayaan dengan akad jual beli. Pembiayaan murabahah pada dasarnya merupakan kesepakatan antara BMT sebagai pemberi modal dan anggota sebagai peminjam. Proses pengembaliannya dibayarkan pada saat jatuh tempo pengembalian.

3) Pembiayaan Mudharabah (MDA). Pembiayaan dengan akad syirkah adalah suatu perjanjian pembiayaan antara BMT dan anggota dimana BMT menyediakan dana untuk penyediaan modal kerja sedangkan peminjamm berupaya mengelolah dana tersebut untuk pengembangan usahanya.

4) Pembiayaan Musyarakah (MSA). Pembiayaan dengan akad syirkah adalah penyertaan BMT sebagai pemilik modal dalam suatu usaha yang mana antara resiko dan keuntungan ditanggung bersama secara berimbang dengan porsi penyertaan.

5) Pembiayaan al-Qardul Hasan, pembiayaan ini hanya didasarkan pada konsep ibadah. Perjanjian pembiayaan antara BMT dengan anggotanya dan hanya anggota yang dianggap layak yang dapat diberikan pinjaman ini.

Pembiayaan barang jasa (sistem murabahah multijasa), produk ini menggunakan akad ijarah. Pembiayaan atas dasar prinsip jasa, disalurkan untuk berbagai jenis kebutuhan halal seperti: ijaroh multijasa untuk pembayaran biaya pendidikan, pengobatan, sewa tempat dan hiwalah untuk anjak hutang-piutang dan pembiayaan tagihan rekening telepon dll (Mardani, 2015).

\section{METODE PENELITIAN}

\section{Jenis Penelitian dan Sumber Data}

Jenis penelitian yang penulis gunakan adalah field research (penelitian lapangan) yang bersifat kualitatif. Penulis menggunakan jenis penelitian ini untuk menganalisis manajemen pembiayaan ijarah pada BMT Al Fataya Payakumbuh, yang dilaksanakan pada 1- 26 Mei 2020, yang diperoleh dari data primer dengan wawancara kepada kepala defisi pembiayaan dan AO BMT Al Fataya Payakumbuh.

\section{Metode Pengumpulan Data}

Adapun metode pengumpulan data yang digunakan oleh penulis yaitu metode wawancara dan dokumentasi. Dalam hal ini penulis melakukan wawancara kepada kepala devisi pembiayaan dan AO BMT Al Fataya Payakumbuh. Data dokumentasi Penulis mengambil laporan jumlah nasabah pembiayaan ijarah pada BMT Al Fataya Payakumbuh.

\section{Teknik Analisis Data}

Langkah-langkah yang dilakukan dalam menganalisis data adalah sebagai berikut: 
a. Reduksi data

Reduksi data merupakan proses pencarian, pemilihan, pemfokusan, dan penyederhanaan data yang relevan dengan masalah yang diteliti. Reduksi data yang dilakukan dalam penelitian ini dilaksanakan secara terus-menerus selama pengumpulan data berlangsung. Langkah-langkah yang dilakukan oleh peneliti dalam melakukan reduksi data adalah sebagai berikut:

1) Data yang diperoleh kemudian dipilih dan disederhanakan sesuai dengan permasalahan serta relevan dengan wawancara dan dokumentasi yang telah didapat.

2) Penulis akan memilih data yang relevan dan bermakna untuk disajikan dengan cara memilih data yang pokok atau inti dari data-data yang telah dirangkum, dan memfokuskan data pada hal-hal yang sesuai.

b. Display Data

Display data atau penyajian data adalah sekumpulan informasi yang tersusun dan memberikan kemungkinan adanya penarikan kesimpulan. Penyajian data dalam penelitian ini berupa penulis menyajikan data yang telah direduksi dan dikategorisasi sebelumnya dalam bentuk tulisan.

c. Penarikan Kesimpulan

Penarikan kesimpulan adalah sebuah penarikan kesimpulan yang menjawab permasalahan yang diungkapkan oleh peneliti sebelumnya (Sugiyono, 2014: 99). Jadi penarikan kesimpulan hanyalah sebagian dari suatu kegiatan dari konfigurasi utuh. Pembuktian kembali atau verifikasi dapat dilakukan untuk mencari pembenaran dan persetujuan, sehingga validitas dapat dicapai. Kesimpulan dalam penelitian ini diperoleh dari reduksi data dan display data.

\section{HASIL DAN PEMBAHASAN}

\section{Pelaksanaan pembiayaan Ijarah pada BMT Al fataya payakumbuh}

Pelaksananan akad ijarah di BMT Al Fataya Payakumbuh ini misalnya untuk biaya pendidikan, diawali dengan pengajuan permohonan pembiayaan pendidikan oleh nasabah kepada BMT Al Fataya Payakumbuh, apabila permohonan pembiayaan dianggap sudah lengkap dan telah memenuhi syarat yang ditentukan oleh pihak BMT, selanjutnya permohonan tersebut disetujui, kemudian BMT membuatkan Akad AlIjarah. Kemudian BMT membayarkan dana yang dipinjam oleh nasabah ke rekening nasabah yang ada di lembaga Pendidikan tempat nasabah menuntut ilmu atau tempat anaknya menuntut ilmu.

Dalam melaksanakan pembiayaan ijarah ini pihak BMT menjalankannya sesuai dengan ketentuan yang ada demi menjaga dan mempertahankan nama baik bahwa BMT Al Fataya payakumbuh menjalankannya sesuai dengan ketentuan dan aturan yang ada 
pada lembaga keuangan syariah pada umumnya. Namun kendala yang dihadapi disini adalah banyak masyarakat yang belum memahami tekni dari pembiayaan ijarah serta minimnya pengetahuan SDM yang ada terkait dengan pelaksanaan akad-akad lembaga keuangan syariah.

\section{Strategi Pemasaran Pembiayaan Ijarah Pada BMT Al Fataya Payakumbuh}

Strategi pemasaran BMT Al Fataya merupakan suatu langkah yang harus ditempuh dalam memasarkan produk barang atau jasa yang terdapat pada BMT tersebut, sehingga apa yang disediakan oleh BMT dapat dikenal oleh masyarakat luas. BMT Al fataya payakumbuh menetapkan sekmen pasarnya yaitu seluruh masyarakat yang beragama Islam.

Berdasarkan hasil wawancara yang penulis lakukan dengan pihak BMT Straregi pemasaran produk pembiayaan Arrum Haji yang dilakukan oleh BMT Al fataya payakumbuh dilihat dari marketing mixnya adalah:

a. Product (produk)

Dilihat dari cara memasarkan produk pembiayaan Ijarah BMT Al fataya payakumbuh menjelaskan tentang keunggulan produk tersebut. pada pembiayaan Ijara tersebut akan membantu nasabah yang keterbatasan dana untuk, dengan adanya pembiayaan ini akan membantu nasabah agar tidak kesulitan dalam mengambil pembiayaan sewa jasa Bentuk strategi produk yang dilakukan oleh BMT Al fataya payakumbuh adalah sebagai berikut:

1) Penentuan moto

Moto merupakan serangkaian kata-kata yang berisikan visi dan misi perusahaan tersebut dalam melayani masyarakat. Baik logo maupun moto di BMT Al fataya payakumbuh telah dirancang dengan baik, karena dalam pembuatan logo dan moto harus memiliki arti dalam artian positif, menarik, dan mudah diingat oleh . Bagi perusahaan apabila kesulitan modal kerja dalam kegiatan bisnisnya dengan cepat untuk mudah memperoleh dana yang diperlukan. Demikian pula pada rumah tangga yang pada suatu saat mengalami kekurangan dana untuk memenuhi kebutuhan rumahtangganya, maka dengan pelayanan yang baik dan berbagai kemudahan dapat memperoleh pembiayaan dari BMT Al fataya payakumbuh

2) Menciptakan merek

Bagi BMT Al fataya payakumbuh dalam mengenalkan produk yang paling diperlukan adalah adanya merek. Ini diharapkan mampu untuk memudahkan konsumen dalam menggunakan produk yang akan ditawarkan

3) Menciptakan kemasan

Kemasan yang dimaksud merupakan pembungkus suatu produk yaitu pelayanan atau jasa dari pihak BMT Al fataya payakumbuh kepada nasabah pada 
BMT Al fataya payakumbuh. Menciptakan kemasan dengan memberikan pelayanan yang terbaik pada nasabah disamping itu juga sebagai pembungkus untuk beberapa jenis jasanya, seperti buku tabungan

Berdasarkan hasil observasi yang penulis lakukan di BMT Al fataya payakumbuh, strategi pemasaran yang dilakukan adalah Pegadaian Syariah menjelaskan tentang produk, baik itu berupa keunggulan yang dimiliki produk ataupun prosedur dalam melaksanakan produk tersebut.

b. Price (harga)

Harga yang diberikan oleh BMT Al fataya payakumbuh adalah mengikuti strategi harga yang ditetapkan oleh kantor wilayah, selanjutnya nasabah akan memilihjangka waktu sesuai dengan harga yang tertera pada simulasi pembiayaan ijarah yang telah disepakati BMT Al fataya payakumbuh

c. Place (tempat)

BMT Al fataya payakumbuh berada di tempat keramaian, lokasi ini berdekatan dengan pusat pemerintahan Kota Payakumbuh. Lokasi kantor cukup strategis, karena berada di pusat kota. Dengan demikian, pemasaran pembiayaan ijarah dapat dilakukan dengan pelaku pasar, disamping nasabah lebih mudah datang ke lokasi BMT Al fataya payakumbuh, lokasi ini juga dilengkapi dengan sarana dan prasarana serta ruangan yang nyaman dan bersih sehingga nasabah nyaman bertransaksi di BMT Al fataya payakumbuh.

Berdasarkan hasil observasi yang penulis lakukan, BMT Al fataya payakumbuh memiliki tempat yang strategis dan berada di sekitar pusat pertokoan masyarakat dan juga dekat dengan pusat kota Payakumbuh. Sehingga pemasaran produk pembiayaan dapat dilakukan dengan mudah. Selain itu, BMT Al fataya payakumbuh memiliki sarana dan prasarana yang lengkap, bersih, dan ruang tunggu yang luas sehingga nasabah nyaman bertransaksi.

d. Promotion (promosi)

Promosi merupakan suatu kegiatan yang secara aktif dilakukan oleh perusahaan untuk mendorong konsumen untuk membeli produk yang ditawarkan. Salah satu tujuan promosi adalah untuk menginformasikan segala jenis produk yang ditawarkan dan berusaha menarik calon nasabah yang baru maupun nasabah lama. BMT Al fataya payakumbuh mempromosikan produk pembiayaan ini sesuai dengan kebutuhan nasabah.

Berdasarkan hasil penelitian tersebut, menurut penulis dalam melakukan strategi pemasaran pembiayaan ijarah yang dilakukan BMT Al fataya payakumbuh sudah sesuai dengan teori yang ada yaitu teori marketing mix diantaranya produk, harga, tempat dan promosi sudah dijalankan dengan baik. Namun, kendala yang dihadapi BMT Al fataya payakumbuh yaitu dibidang sumber daya manusia yang ada di BMT Al fataya payakumbuh sendiri. Karena sebagian besar dari karyawan 
berlatar belakang pendidikan umum tidak berlatar belakang pendidikan ekonomi syariah atau agama. Sehingga banyak dari karyawan belum bisa menjelaskan secara maksimal tentang produk kepada calon nasabah yang memiliki keraguan tentang apakah produk ini benar-benar terhindar dari riba, gharar, dan maysir.

\section{KESIMPULAN}

Pelaksananan akad ijarah di BMT Al Fataya Payakumbuh diawali dengan pengajuan permohonan pembiayaan pendidikan oleh nasabah kepada BMT Al Fataya Payakumbuh, apabila permohonan pembiayaan dianggap sudah lengkap dan telah memenuhi syarat yang ditentukan oleh pihak BMT, selanjutnya permohonan tersebut disetujui, kemudian BMT membuatkan Akad Al- Ijarah. Kemudian BMT membayarkan dana yang dipinjam oleh nasabah ke rekening nasabah yang ada di lembaga Pendidikan tempat nasabah menuntut ilmu atau tempat anaknya menuntut ilmu. Dalam melaksanakan pembiayaan ijarah ini pihak BMT menjalankannya sesuai dengan ketentuan yang ada demi menjaga dan mempertahankan nama baik bahwa BMT Al Fataya payakumbuh menjalankannya sesuai dengan ketentuan dan aturan yang ada pada lembaga keuangan syariah pada umumnya. Namun kendala yang dihadapi disini adalah banyak masyarakat yang belum memahami tekni dari pembiayaan ijarah serta minimnya pengetahuan SDM yang ada terkait dengan pelaksanaan akad-akad lembaga keuangan syariah.

Straregi pemasaran produk pembiayaan Arrum Haji yang dilakukan oleh BMT Al fataya payakumbuh dilihat dari marketing mixnya adalah: Product (produk), Price (harga), Place (tempat), Promotion (promosi). Jadi dapat disimpulkan bahwa masih kurangnya strategi pemasaran yang dilakukan oleh BMT Al fataya di payakumbuh.

\section{DAFTAR PUSTAKA}

Antonio, M. S. i. (2001). Bank Syariah: dari teori ke praktik: Gema Insani.

Ascarya. 2007. Akad dan Produk Bank Syariah. Jakarta: PT Raja GrafindoPersada

Indonesia, I. B. 2015. Mengelolah Bisnis Pembiayaan Bank Syariah. Jakarta: PT gramedia Pustaka Utama

Karim, A. (2010). Bank Islam: Analisis Fiqh dan Keuangan (Edisi Keempat). Jakarta (ID): PT. Raja Grafindo Persada.

Kasmir, S. (2018). Pemasaran Bang: Prenada Media.

Mafruhah, I. (2007). Membumikan Konsep Syari'ah Dalam Ekonomi Berbasis Kerakyatan (Baitul Maal Wat Tamwil Sebagaisebuah Solusi). Jurnal Ekonomi Pembangunan: Kajian Masalah Ekonomi dan Pembangunan, 3(2), 195-205.

Mardani, M. (2015). Aspek Hukum Lembaga Keuangan Syariah Di Indonesia: Prenada Media.

Muhammad, H. (2004). Manajemen dana bank syariah: Ekonisia. 
Rivai, V., \& Veithzal, A. P. (2008). Islamic financial management: teori, konsep dan aplikasi panduan praktis untuk lembaga keuangan, nasabah, praktisi, dan mahasiswa: Rajawali Press.

Saputra, M. N. 2016. Optimalisasi Peran Baitul Maal Pada BMT untuk Pemberdayaan Uasaha Mikro di Jawa Timur. Jurnal Masharif al Syariah: Jurnal Ekonomi dan Perbankan Syariah Vo. 1 No. 2

Santoso, H., \& Anik, A. (2015). Analisis Pembiayaan Ijarah Pada Perbankan Syariah. Jurnal Ilmiah Ekonomi Islam, 1(02).

Soemitra, A. (2017). Bank \& Lembaga Keuangan Syariah: Prenada Media.

Sugiyono. 2014. Metode Penelitian Pendidikan. Bandung: Alfabet

Sulhan, M., \& Siswanto, S. (2008). Manajemen Bank: Konvensional dan Syariah: UINMaliki Press.

Yudiana, F. E. Y. (2014). Manajemen Pembiayaan Bank Syariah: STAIN Salatiga Press.

Yunus, J. L. (2009). Manajemen bank syariah mikro: UIN-Maliki Press. 